\title{
Decidua Produces a Protein that Inhibits Choriogonadotrophin Release from Human Trophoblasts
}

\author{
Song-Guang Ren and Glenn D. Braunstein \\ Department of Medicine, Cedars-Sinai Medical Center, University of California \\ at Los Angeles School of Medicine, Los Angeles, California 90048
}

\begin{abstract}
To test the hypothesis that uterine decidua may modulate trophoblast function, trophoblasts and decidual cells were isolated from term placentas by enzymatic digestion and Percoll gradient centrifugation. Placental trophoblasts were cocultured with decidual cells and trophoblasts or JEG-3 choriocarcinoma cells were incubated with medium conditioned by decidual cells (DCM) for 72-96 h. In cocultures decidual cells inhibited choriogonadotropin (hCG) release from trophoblasts by $75 \%$ in comparison with controls $(P<0.001)$. The DCM contained a factor that markedly inhibited hCG release from trophoblasts and JEG cells in vitro compared with controls. The inhibitory effect of the factor on hCG release was dose dependent, and could be eliminated by boiling the DCM for 30 min or proteolytic enzyme treatment. Ultrafiltration and Sephadex G-50 fractionation of the DCM indicated that the apparent molecular mass was 7,000-10,000 D. DCM also inhibited the stimulatory effect of exogenous CAMP on hCG secretion by JEG-3 cells, suggesting that DCM may interfere with activation of the cAMP-dependent protein kinases or transcription of hCG genes. These results suggest that the release of trophoblast hCG is under local paracrine control, regulated in part by a protein released by decidual cells. (J. Clin. Invest. 87:326330.) Key words: choriogonadotropin • pregnancy • trophoblast - placenta $\bullet$ decidua $\bullet$ prolactin
\end{abstract}

\section{Introduction}

The intimate relationship between placental trophoblasts and the decidual lining of the endometrium during pregnancy raises the strong possibility that each may influence the function of the other. Indeed, prior studies have shown that the placenta releases a polypeptide that stimulates synthesis and release of decidual prolactin $(1,2)$. Yuen and co-workers have also suggested that prolactin inhibits choriogonadotropin (hCG) ${ }^{1}$ production from term trophoblasts (3). IL-1 produced by placental phagocytic cells and decidual cells stimulates trophoblast hCG secretion $(4,5)$ and in turn hCG may have tro-

Address reprint requests to Dr. Glenn D. Braunstein, Dept. of Medicine, Rm. B1 18, Cedars-Sinai Medical Center, 8700 Beverly Blvd., Los Angeles, CA 90048.

Received for publication 18 January 1990 and in revised form 30 July 1990.

1. Abbreviations used in this paper: DCM, medium conditioned by decidual cells; hCG, choriogonadotropin; hPL, human placental lactogen; PP12, placental protein 12; PRL, prolactin.

J. Clin. Invest.

(c) The American Society for Clinical Investigation, Inc.

$0021-9738 / 91 / 01 / 0326 / 05 \$ 2.00$

Volume 87, January 1991, 326-330 phic effects on the proliferation of trophoblast (6) and lymphocytes (7). Recently, Vicovac and Genvacev have provided evidence through a coincubation study of trophoblast and decidua that the decidua has an inhibitory effect on the synthesis of hCG and total protein by trophoblast cells (8). Thus, the decidua and trophoblast each appear to have a paracrine effect on the other.

This study was undertaken to evaluate the effect of the decidua upon hCG production and secretion by the trophoblast and to determine the specificity and some of the properties of the substance which has been shown to inhibit hCG production in the coculture experiments.

\section{Methods}

Preparation of cells. Term placenta and associated membranes were obtained from 10 healthy pregnant women undergoing cesarean section. Cytotrophoblasts were isolated from villus tissue using the method of Kliman et al. (9). Briefly, washed villus tissue was minced and then digested with $0.125 \%$ trypsin (Sigma Chemical Co., St. Louis, $\mathrm{MO}$ ) and $0.2 \mathrm{~g} /$ liter DNase (Sigma) at $37^{\circ} \mathrm{C}$ for $30 \mathrm{~min}$. Dispersed tissue was applied to a 5-70\% Percoll (Sigma) gradient. After centrifugation at $1,200 \mathrm{~g}$, the middle layer containing cytotrophoblasts was collected and washed. Decidual cells were isolated from decidual tissue dissected from placental membranes by the method of Braverman et al. (10). This procedure involved the digestion of decidual tissue with $0.25 \%$ collagenase A (Boehringer-Mannheim, Indianapolis, IN) at $37^{\circ} \mathrm{C}$ for $2 \mathrm{~h}$ followed by centrifugation through a $20-60 \%$ Percoll gradient. Cell viability was $>90 \%$ using trypan blue exclusion. Human choriocarcinoma cell line JEG-3 was purchased from American Type Culture Collection (Rockville, MD).

Cell incubation. In coculture studies, the trophoblast $\left(1 \times 10^{6}\right.$ cells/ $\mathrm{ml}$ per well) or decidual cells $\left(0.83-7.5 \times 10^{5}\right.$ cells $/ \mathrm{ml}$ per well), or trophoblast plus decidual cells (sum of both cell numbers $/ 2 \mathrm{ml}$ per well) were cultured in 24-multiwell culture plates with $16-\mathrm{mm}$ well diameter (Costar Data Packaging Corp., Cambridge, MA) containing CMRL 1066 medium (Gibco Laboratories, Grand Island, NY) supplemented with $10 \%$ fetal bovine serum (Gibco), $25 \mathrm{mM}$ Hepes (Sigma), $1 \mathrm{U} / \mathrm{ml}$ insulin (Nordisk Gentofte A/S, Gentofte, Denmark), $10 \mathrm{mM}$ glutamine (Irvine Scientific, Santa Ana, CA), $100 \mathrm{U} / \mathrm{ml}$ penicillin, and 100 $\mu \mathrm{g} / \mathrm{ml}$ streptomycin (Gibco) in an atmosphere of $5 \% \mathrm{CO}_{2}: 95 \%$ air at $37^{\circ} \mathrm{C}$ for $120 \mathrm{~h}$. The medium was removed and replaced each $24 \mathrm{~h}$.

In other studies, the trophoblast $\left(1 \times 10^{6}\right.$ cells $/ 2 \mathrm{ml}$ per well $)$ or JEG-3 $\left(1 \times 10^{5}\right.$ cells $/ 2 \mathrm{ml}$ per well $)$ were precultured for $24 \mathrm{~h}$. After removing the precultured medium, the cells were cultured in control medium or medium containing test substances. In all experiments, the media contained the same volume of CMRL 1066. In addition, in some trophoblast experiments and all of the JEG-3 cell experiments, the control medium contained the same volume of $0.01 \mathrm{M}$ PBS (pH 7.4) as was used to dissolve the test substance in the experimental media. In the time course studies, the medium was removed and replaced with control or experimental medium each $24 \mathrm{~h}$ during $72-96 \mathrm{~h}$ incubation period. In other experiments, the medium in both control and experimental wells were removed at termination of the experiments after $72 \mathrm{~h}$ incubation.

The spent media were centrifuged and the supernatants stored at $-20^{\circ} \mathrm{C}$ until hormone assay. In each experiment, all treatments were 
tested in three to four wells. Each variable was tested in at least two separate experiments.

Preparation and studies with decidual conditioned medium. Decidual conditioned medium (DCM) was prepared by incubating decidual cells $\left(5-7.5 \times 10^{6} / 10 \mathrm{ml}\right.$ per flask) in $75-\mathrm{cm}^{2}$ cell culture flask (Costar) containing CMRL 1066 medium for 24-72 h. In the time course experiments, DCM was removed each $24 \mathrm{~h}$ and used for the next 24-h treatment of trophoblast cells that were derived from the same placenta as were the decidual cells. In other studies, DCM was removed during the first 36-48 $\mathrm{h}$ of incubation. After the medium was decanted from decidual cells and centrifuged, the supernatant was collected for use. In dose-response experiments, the different doses of DCM were prepared by dilution with $0.01 \mathrm{M}$ PBS buffer. The effect of proteolytic enzyme treated on DCM was evaluated by incubating DCM for $16 \mathrm{~h}$ at $37^{\circ} \mathrm{C}$ with trypsin or chymotrypsinogen-A (Sigma, $40 \mu \mathrm{g}$ enzyme/mg DCM protein), followed by the addition of $5 \mu \mathrm{g} \alpha$-1-antitrypsin/ $\mu \mathrm{g}$ (Sigma) trypsin to the treated DCM with incubation at $37^{\circ} \mathrm{C}$ for an additional 4 h. The same weight of BSA (Sigma) as DCM was added to CMRL 1066 medium, which served as a control, and the medium was treated as described above (60 $\mu \mathrm{g}$ enzyme/mg BSA). DCM was also tested after heating to $100^{\circ} \mathrm{C}$ for $30 \mathrm{~min}$ in a water bath.

The approximate molecular size of the active fraction of DCM was evaluated through ultrafiltration and gel chromatography. DCM was ultrafiltered through an Amicon diaflo apparatus (Amicon Corp., Danvers, MA) with a YM-10 membrane that has a molecular exclusion limit of 10,000 . The $>10,000$ and the $<10,000-\mathrm{D}$ fractions were tested. In some experiments, $20 \mathrm{ml}$ DCM was concentrated by ultrafiltration using an Amicon YM-2 membrane with a cutoff of 1,000 D followed by lyophilization of the concentrated DCM. The lyophilized DCM was resuspended in $0.5 \mathrm{ml} 0.01 \mathrm{M}$ PBS buffer (pH 7.4) and applied to a $1 \times 25 \mathrm{~cm}$ Sephadex G-25 or G-50 column and eluted with the same buffer. Column characteristics were: $V_{0}=10.5 \mathrm{ml} ; V_{t}=45 \mathrm{ml}$ and $35 \mathrm{ml}$ for G-25 and G-50, respectively. 25 drops per fraction were collected. Several contiguous fractions were pooled and tested at a concentration of $25 \%$ of the pool for ability to inhibit hCG in the JEG cells.

CMRL 1066 media collected following 36-48 h of incubation with AV-3 cells $\left(5 \times 10^{6}\right.$ cells $/ 10 \mathrm{ml}$ per flask $)$, or RPMI 1788 cells $\left(5 \times 10^{6}\right.$ cells $/ 10 \mathrm{ml}$ per flask), purchased from American Type Tissue Collection, were used as negative controls. For positive control purposes, 0.5 mM 8-bromo-cAMP (Sigma) was used to stimulate the JEG or trophoblast cells (11). Another positive control for the system was composed of incubation of decidual cells for $96 \mathrm{~h}$ in medium derived from trophoblast culture, with measurement of prolactin (PRL) and placental protein 12 (PP12; insulin-like growth factor-I-binding protein) as indices of decidual protein production.

Measurements of hormones and proteins. hCG, human placental lactogen (hPL), PRL, and PP12 in the media were measured by homologous radioimmunoassay methods as previously described (12-15). Sensitivity of the assays were $1 \mathrm{ng} / \mathrm{ml}$ for hCG and hPL, $1.7 \mathrm{ng} / \mathrm{ml}$ for PRL, and $7.8 \mathrm{ng} / \mathrm{ml}$ for PP12. The protein content of the cells and media were measured by the method of Bradford (16), using BSA as a standard, and Bio-Rad protein reagents (Bio-Rad Laboratories, Richmond, CA). Concentrations of the hormones in the media were expressed as $\mathrm{ng} / \mathrm{mg}$ protein or $\mathrm{ng} /$ well.

Statistical analysis. All results were presented as the mean \pm SEM. Student's $t$ test with the Bonferroni correction was used for determining the statistical significance of the difference between control and experimental groups. A $P<0.05$ was considered to be significant.

\section{Results}

In the coculture of trophoblast and decidual cells over $120 \mathrm{~h}$ incubation, $1 \times 10^{6}$ trophoblast cells released $112.1 \pm 20.0 \mathrm{ng}$ $\mathrm{hCG} /$ well per $120 \mathrm{~h}$, while trophoblast plus an average (from three experiments) of $5.75 \times 10^{5}$ decidual cells released 28.2 $\pm 4.1 \mathrm{ng} \mathrm{hCG} /$ well per $120 \mathrm{~h}$. Thus, the trophoblast cells cocultured with decidual cells released $75 \%(P<0.001)$ less hCG than did trophoblast cultured alone. The degree of inhibi- tion of trophoblast hCG secretion by decidual cells was dependent upon the number of decidual cells, with a progressively greater inhibition as the number of decidual cells seeded were increased (Fig. 1).

Primary trophoblast cells cultured in CRML 1066 medium containing 50\% DCM released $45 \%(P<0.005), 64 \%(P$ $<0.001), 66 \%(P<0.005)$, and 70\% $(P<0.005)$ less hCG than did control cultures at $24,48,72$, and $96 \mathrm{~h}$, respectively (Fig. 2). hPL release from primary trophoblast cultures exposed for $96 \mathrm{~h}$ to $50 \%$ DCM was significantly increased (Table I). Decidual cells exposed for $96 \mathrm{~h}$ to $50 \%$ trophoblast cell culture medium showed significant stimulation of PRL secretion in the medium compared with control decidual cultures, but PP12 release remained unchanged (Table I).

JEG-3 cells exposed for $72 \mathrm{~h}$ to $25 \%$ DCM also had a significant reduction in hCG secretion into the medium compared to control cultures, but there was neither stimulation nor inhibition of hPL release. Control media obtained from incubation with AV-3 cells or RPMI 1788 cells incubated under the same conditions as the decidual cells for $36-48 \mathrm{~h}$ had no inhibitory effects on hCG release from the JEG-3 cells (Table II). $0.5 \mathrm{mM}$ 8-bromo-cAMP markedly stimulated hCG secretion; however, DCM, but not conditioned medium from RPMI 1788 cells, significantly reduced the stimulant effect of 8-bromo-cAMP on hCG secretion in a dose-dependent manner (Fig. 3).

The inhibitory effect of DCM on hCG release by primary trophoblast cells and JEG-3 cells was dose dependent as depicted in Fig. 4. The inhibitory activity of DCM was lost following heating at $100^{\circ} \mathrm{C}$ for 30 min or treatment with trypsin or chymotrypsin (Table II). After ultrafiltration, the hCG inhibitory activity was found in the $<10,000$-D fraction, and eluted in the 7,200-9,800-D fractions after Sephadex G-50 or G-25 chromatography of the DCM (Fig. 5). This fraction contained $18.6 \%$ of the protein eluted from the column.

\section{Discussion}

The results of our study indicate that the human decidual cell secretes a factor that inhibits hCG release by placental trophoblasts or JEG-3 cells in vitro. The inhibition was DCM dose dependent and specific since the DCM stimulated hPL release from primary trophoblast cultures and did not alter hPL secre-

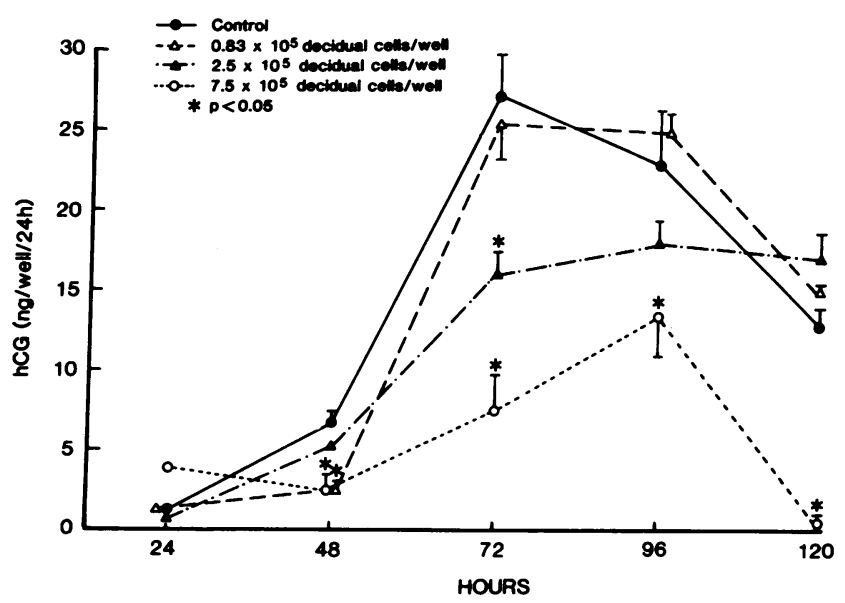

Figure 1. The relationship between hCG release by trophoblast cells and initial decidual cell concentration in coculture of trophoblast cells $\left(1 \times 10^{6} /\right.$ well $)$ and decidual cells during $120 \mathrm{~h}$ of incubation. 


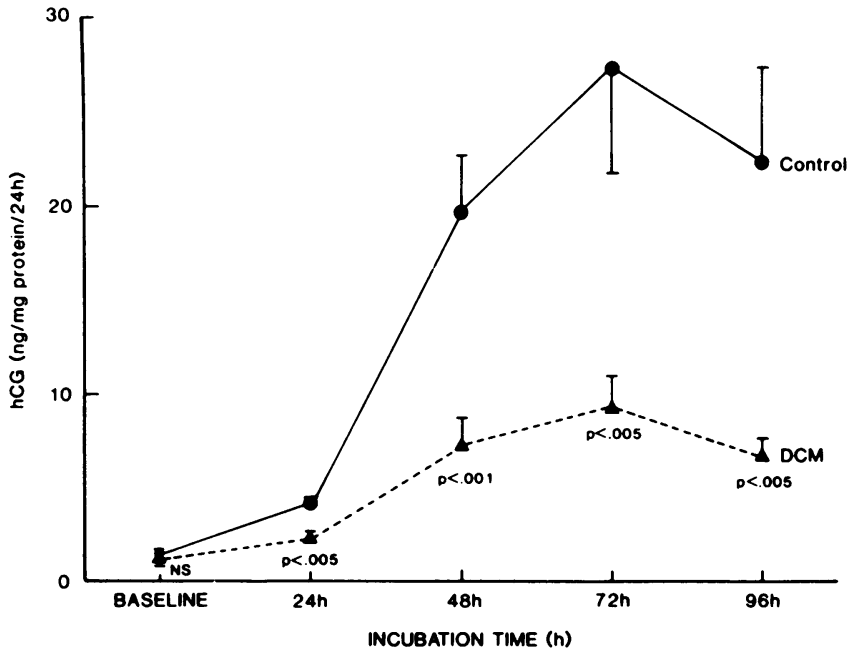

Figure 2. Time course of inhibition of hCG release from primary trophoblast cell cultures by DCM. Trophoblast cells were exposed to control medium or $50 \%$ DCM. The medium was removed and replaced with control medium or DCM each $24 \mathrm{~h}$ during the 96-h incubation period. Each point presents the mean of 20 wells in three different placental experiments.

tion by JEG-3 cells. The failure of DCM to stimulate hPL release from JEG-3 cells may be due to the paucity of hPL production by these cells. DCM also did not inhibit total protein synthesis by JEG-3 cells or placental trophoblasts. The specificity of this effect is supported further by the absence of hCG inhibition in JEG-3 cells incubated with media derived from AV-3 or RPMI 1788 cells. The similar qualitative secretory pattern of hCG from primary trophoblast cells incubated with DCM in comparison to trophoblast cells incubated with control media (Fig. 2) also indicates that the effect is not due to nonspecific inhibition since the peak of hCG release occurred at $72 \mathrm{~h}$ of incubation with or without DCM exposure. We and others have previously demonstrated a similar time course of hCG secretion in primary trophoblast cultures (17-18). The presence of a decidual inhibitor of hCG secretion by early placental trophoblasts was also demonstrated by Vicovac and Genvacev (8). It is interesting that Golander and his colleagues suggested

Table I. Interaction of Trophoblast and Decidual Cell on Hormones and Protein Release

\begin{tabular}{lccccc}
\hline & \multicolumn{2}{c}{ Trophoblast cell culture } & & \multicolumn{2}{c}{ Decidual cell culture } \\
\cline { 2 - 3 } \cline { 5 - 6 } $\begin{array}{l}\text { Hormone } \\
\text { or protein }\end{array}$ & Control & $\begin{array}{c}\text { Treated } \\
\text { with DCM }\end{array}$ & & Control & $\begin{array}{c}\text { Treated with } \\
\text { trophoblast media }\end{array}$ \\
\cline { 5 - 6 } & \multicolumn{5}{c}{$n g /$ mg protein } \\
hCG & $75 \pm 14$ & $26 \pm 4^{*}$ & - & - \\
hPL & $281 \pm 59$ & $724 \pm 61^{* *}$ & - & - \\
PRL & - & - & $690 \pm 81$ & $1,039 \pm 42^{* *}$ \\
PP12 & - & - & $545 \pm 22$ & $587 \pm 47$
\end{tabular}

Trophoblast cell (or decidual cell) exposed for $96 \mathrm{~h}$ to $50 \% \mathrm{DCM}$ (or trophoblast culture medium). Each hormone level in the medium is mean \pm SEM of 20 wells from three different placental experiments. ${ }^{*} P<0.005 ;{ }^{* *} P<0.001$ compared with control.
Table II. Effects of DCM or Control Media on hCG Release by JEG-3 Cells

\begin{tabular}{lc}
\hline \multicolumn{1}{c}{ Treatment } & hCG \\
\hline & $n g / m g$ protein \\
Control & $103 \pm 6$ \\
25\% DCM & $66 \pm 12^{*}$ \\
25\% Boiled DCM & $90 \pm 12$ \\
Control & $162 \pm 34$ \\
25\% DCM & $92 \pm 10^{*}$ \\
Medium treated by trypsin & $150 \pm 41$ \\
25\% DCM treated by trypsin & $134 \pm 24$ \\
Medium treated by chymotrypsin & $139 \pm 18$ \\
25\% DCM treated by chymotrypsin & $156 \pm 27$ \\
Control & $76 \pm 6$ \\
25\% AV-3 cell medium & $64 \pm 7$ \\
25\% RPMI cell medium & $73 \pm 6$
\end{tabular}

JEG-3 cell exposed for $72 \mathrm{~h}$ to DCM with different treatments, or 0.5 $\mathrm{mM}$ cAMP or control cell media. The hCG value in media is mean \pm SEM of six wells from at least two experiments.

${ }^{*} P<0.05$ compared with control.

over a decade ago that the rise in hCG secretion over $72 \mathrm{~h}$ from placental explant cultures may reflect a loss of an endogenous hCG inhibitory factor that is removed from the culture during media changes (19).

Preliminary characterization of the inhibitory factor indicates that it is a protein with a molecular weight between 7,000 and 10,000 D. Yuen and associates suggested that PRL inhibits hCG production in vitro and in vivo (3). Since the decidual cell is a primary source of PRL during pregnancy (20), it is conceivable that PRL or a fraction of PRL would account for our results. This is unlikely since PRL has a molecular mass of 22,500 D whereas our inhibitory factor has a molecular mass of $<10,000 \mathrm{D}$ and the average concentration of immunoreactive PRL in our DCM was $\sim 200 \mathrm{ng} / \mathrm{ml}$ which does not inhibit

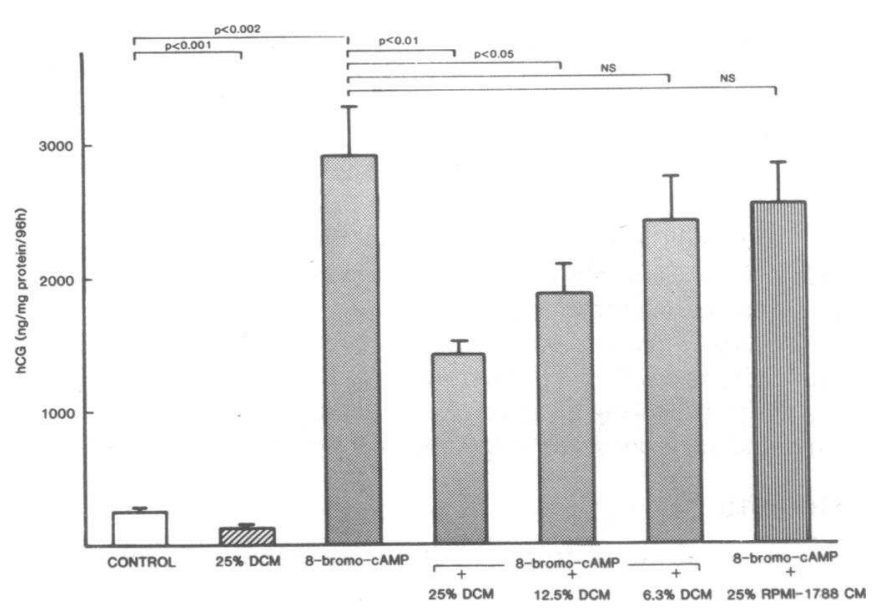

Figure 3. DCM inhibition of the stimulatory effect of cAMP on hCG secretion by JEG-3 cells. JEG-3 cells were exposed to control media, 25\% DCM, 0.5 mM 8-bromo-cAMP plus different doses of DCM, or $0.5 \mathrm{mM}$ 8-bromo-cAMP plus 25\% RPMI 1788 cell conditioned media for $72 \mathrm{~h}$. 


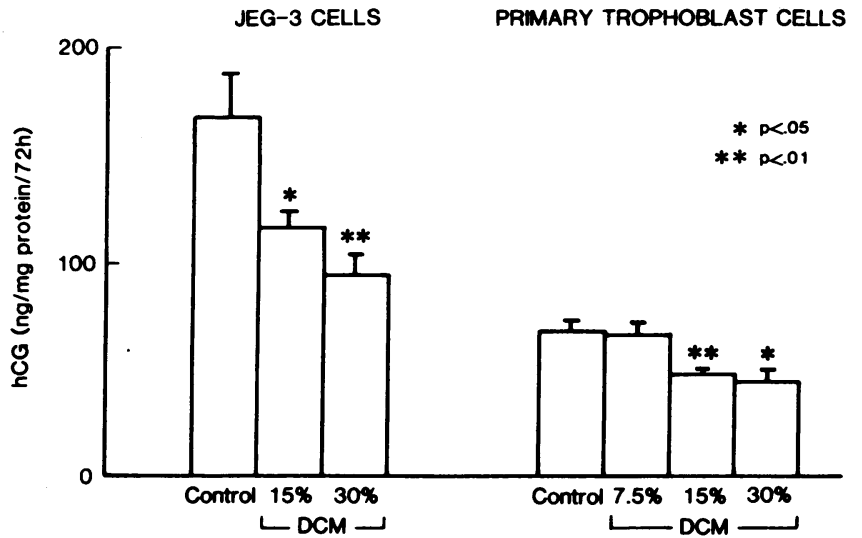

Figure 4. Dose response relationship between DCM and hCG release. JEG-3 cells and trophoblast cells were exposed to different concentrations of DCM for $72 \mathrm{~h}$. Each bar represents mean \pm SEM of hCG in six wells.

hCG release from trophoblast cells in our hands (unpublished observations). Progesterone has also been found by some investigators to inhibit hCG production by placental tissue in vitro (21-23). Since progesterone is synthesized by the trophoblast rather than the decidual cells and since the active hCG inhibitory factor in DCM is destroyed by heat and proteolytic enzymes, it is unlikely that progesterone is responsible for the hCG inhibition.

The mechanisms by which the decidual cell factor inhibits hCG secretion by the trophoblast or JEG-3 cells are unclear, but our data do indicate that direct decidua-trophoblast cell contact is not required for regulation of hCG production. Since DCM inhibited the stimulant effect of exogenous cAMP on hCG secretion by trophoblasts in our study, DCM may interfere with activation of the cAMP-dependent protein kinases of placenta (24), or transcription of genes encoding the $\alpha$ - and $\beta$-subunits of hCG regulated by cAMP (25). It is of interest that trophoblast hPL secretion was stimulated by DCM, a finding that is consistent with those of Fay et al. (26). The different secretory behavior of hCG and hPL in trophoblast cell cultures exposed to the same DCM supports our previous observations

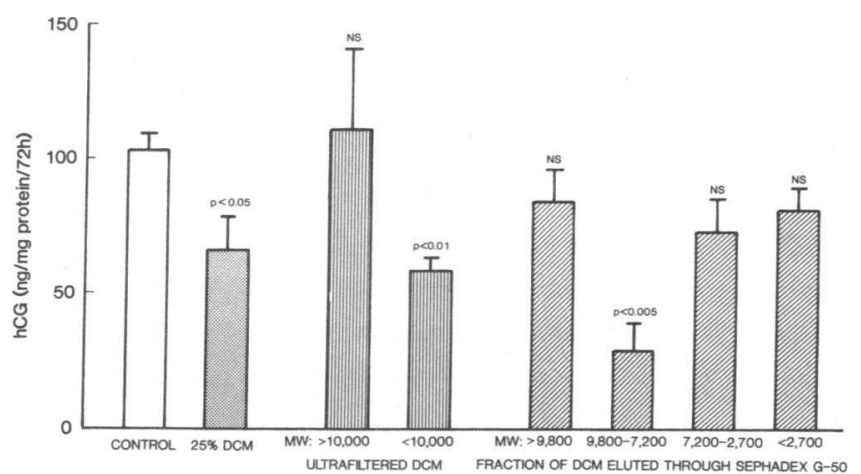

Figure 5. The inhibitory activity of different fractions of DCM fractionated by ultrafiltration and chromatography. JEG-3 cells were exposed for $72 \mathrm{~h}$ to control medium, 25\% DCM, ultrafiltrated (through YM-10), or chromatographed (through Sephadex G-50) fractions of DCM. Each bar represents the mean + SEM of hCG in six wells from at least two experiments. that the physiological regulation of secretion of different placental protein hormones may differ (18). It is unknown whether the different action of DCM on hPL and hCG release resides in the same substance or in different substances.

Our results also confirm the finding that placental tissue stimulates PRL production by decidual cells $(1,2)$. Trophoblast cell culture medium did not, however, change PP12 release from decidual cells indicating that decidual PRL and PP12 regulation are under different control.

In summary, this study offers strong evidence that hCG secretion by trophoblast cells is regulated in part by the decidual cells and decidual protein production is modulated in part by trophoblast cells. This supports the hypothesis that a paracrine regulation of decidua and trophoblast function exists.

\section{Acknowledgments}

We thank Ms. Judith Seliktar and Ms. Elisa Gonzales for their technical assistance, and Ms. Helene Zauderer for her secretarial help. The provision of reagents by the National Hormone and Pituitary Program (Baltimore, MD) and Dr. Hans Bohn (Behringwerk, West Germany) is gratefully acknowledged.

\section{References}

1. Handwerger, S., S. Barry, E. Markoff, J. Barrett, and P. M. Conn. 1983. Stimulation of the synthesis and release of decidual prolactin by a placental polypeptide. Endocrinology. 112:1370-1374.

2. Handwerger, S., D. Capel, G. Korner, and R. Richards. 1987. Purification of decidual prolactin-releasing factor, a placental protein that stimulates prolactin release from human decidual tissue. Biochem. Biophys. Res. Commun. 147:452459.

3. Yuen, B. H., Y. S. Moon, and D. H. Shin. 1986. Inhibition of human chorionic gonadotropin production by prolactin from term human trophoblast. Am. J. Obstet. Gynecol. 154:336-340.

4. Flynn, A., J. H. Finke, and M. L. Hilfiker. 1982. Placental mononuclear phagocytes as a source of interleukin-1. Science (Wash. DC). 218:475-476.

5. Yagel, S., P. K. Lala, W. A. Powell, and R. F. Casper. 1989. Interleukin-1 stimulates human chorionic gonadotropin secretion by first trimester human trophoblast. 1989. J. Clin. Endocrinol. \& Metab. 68:992-995.

6. Yagel, S., R. F. Casper, W. Powell, R. S. Parhar, and P. K. Lala. 1989. Characterization of pure human first-trimester cytotrophoblast cells in long-term culture: growth pattern, markers, and hormone production. Am. J. Obstet. Gynecol. 160:938-945.

7. Yagel, S., R. S. Parhar, and P. K. Lala. 1989. Trophic effects of first-trimester human trophoblasts and human chorionic gonadotropin on lymphocyte proliferation. Am. J. Obstet. Gynecol. 160:946-953.

8. Vicovac, L. J., and O. Genbacev. 1988. Coincubation - an experimenta approach to the study of decidual-trophoblast interaction. Placenta. 9:109-115.

9. Kliman, H. J., J. E. Nestler, E. Sermasi, J. M. Sanger, and J. F. Strauss III. 1986. Purification, characterization, and in vitro differentiation of cytotrophoblasts from human term placentae. Endocrinology. 118:1567-1582.

10. Braverman, M. B., A. Bagni, D. de Ziegler, T. Den, and E. Gurpide. 1984. Isolation of prolactin-producing cells from first and second trimester decidua. $J$. Clin. Endocrinol. \& Metab. 58:521-525.

11. Nulsen, J. C., M. J. Woolkalis, G. S. Kopf, and J. F. Struass III. 1988. Adenylate cyclase in human cytotrophoblasts: characterization and its role in modulating human chorionic gonadotropin secretion. J. Clin. Endocrinol. \& Metab. 66:258-265.

12. Braunstein, G. D., W. G. Karow, W. C. Gentry, J. Rasor, and M. E. Wade. 1978. First-trimester chorionic gonadotropin measurements as an aid in the diagnosis of early pregnancy disorders. Am. J. Obstet. Gynecol. 131:25-32.

13. Braunstein, G. D., J. L. Rasor, E. Engvall, and M. E. Wade. 1980. Interrelationships of human chorionic gonadotropin, human placental lactogen, and pregnancy-specific $\beta 1$-glycoprotein throughout normal human gestation. Am. J. Obstet. Gynecol. 138:1205-1213.

14. Salacinski, P. R. P., C. McLean, J. E. C. Sykes, V. V. Ciement-Jones, and P. J. Lowry. 1981. Iodination of proteins, glycoproteins, and peptides using a solid-phase oxidizing agent, 1,3,4,6-tetrachloro-3 $\alpha, 6 \alpha$-diphenylglycoluril (iodogen). Anal. Biochem. 117:136-146.

15. Rutanen, E-M., H. Bohn, and M. Seppala. 1982. Radioimmunoassay of placental protein 12: levels in amniotic fluid, cord blood, and serum of healthy 
adults, pregnant women, and patients with trophoblastic disease. Am. J. Obstet. Gynecol. 144:460-463.

16. Bradford, M. M. 1976. A rapid and sensitive method for the quantitation of microgram quantities of protein utilizing the principle of protein-dye binding. Anal. Biochem. 72:248-254.

17. Kato, Y., and G. D. Braunstein. 1989. Discordant secretion of placental protein hormones in differentiating trophoblasts in vitro. J. Clin. Endocrinol. \& Metab. 68:814-819.

18. Lobo, J. O., and F. L. Bellino. 1989. Estrogen synthetase (aromatase) activity in primary culture of human term placental cells: effects of cell preparation, growth medium, and serum on adenosine $3^{\prime}, 5^{\prime}$-monophosphate response. $J$. Clin. Endocrinol. \& Metab. 69:868-874.

19. Golander, A., J. R. Barrett, L. Tyrey, W. H. Fletcher, and S. Handwerger 1978. Differential synthesis of human placental lactogen and human chorionic gonadotropin in vitro. Endocrinology. 102:597-605.

20. Luciano, A. A., I. A. Maslar, W. F. Kusmik, and D. H. Riddick. 1980 Stimulatory activity of serum on prolactin production by human decidua. Am. $\mathrm{J}$. Obstet. Gynecol. 138:665-669.

21. Maruo, T., H. Matsuo, T. Ohtani, M. Hoshina, and M. Mochizuki. 1986. Differential modulation of chorionic gonadotropin (CG) subunit messenger ribo- nucleic acid levels and CG secretion by progesterone in normal placenta and choriocarcinoma cultured in vitro. Endocrinology. 119:855-864.

22. Wilson, E. A., M. J. Jawad, and L. R. Dickson. 1980. Suppression of human chorionic gonadotropin by progestational steroids. Am. J. Obstet. Gynecol. 138:708-713.

23. Barnea, E. R., and M. Kaplan. 1989. Spontaneous, gondotropin-releasing hormone-induced, and progesterone-inhibited pulsatile secretion of human chorionic gonadotropin in the first trimester placenta in vitro. J. Clin. Endocrinol. \& Metab. 69:215-217.

24. Cermerikic-Jakic, B., and M. Pavlovichournac. 1984. Modification of protein kinase pattern in human placenta during gestation. Placenta. 5:443-453.

25. Jameson, J. L., R. C. Jaffe, S. L. Gleason, and J. F. Habener. 1986. Transcriptional regulation of chorionic gonadotropin $\alpha$ - and $\beta$-subunit gene expression by 8-bromo-adenosine 3', 5'-monophosphate. Endocrinology. 119:25602567.

26. Fay, T., I. Jacobs, B. Teisner, R. Silman, and G. Grudzinskas. 1988. New techniques in the identification and quantification of proteins synthesized de novo in tissue explants: application to examine decidual-trophoblast interaction. 11th Rochester Trophoblast Conference with the European Placenta Group. Abstr. 108. 